\title{
JUURNAL.RU
}

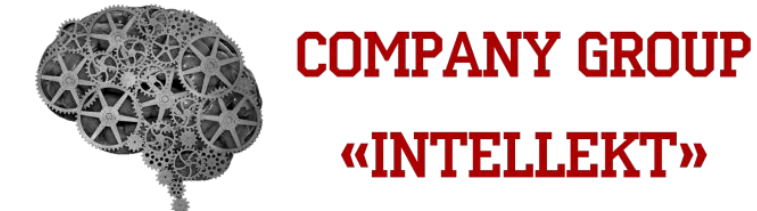

Исмагилова Г.Р., Никитина В.С. Бамкирский государственный университет

Уфа, Россия

doi: 10.18411/lj2016-6-1-11

\section{Проблемы создания биоразлагаемых полимеров}

Глобальное загрязнение окружающей среды полимерными отходами обуславливает создание биоразлагаемых полимеров (БРП), деструктирующих на экологически безвредные компоненты под действием природных микроорганизмов в относительно короткие сроки.

На сегодняшний день можно выделить четыре основных метода создания биоразлагаемых полимерных материалов: микробиологический синтез (полигидроксиалканоаты), химический синтез из биотехнологически полученных мономеров (полилактиды), придание традиционным синтетическим полимерам способности к биодеструкции и модификация природных полимеров [1].

Хотя использование БРП очень перспективно, на пути их синтеза встречается множество проблем. Самая главная проблема удерживающая темпы развития БРП - это их высокая стоимость по сравнению с традиционными синтетическими аналогами (в 2,5-7 раз дороже), также ограниченные возможности крупнотоннажного производства $[2,3]$. Для производства некоторых биоразлагаемых полимеров в качестве сырья используется пищевое зерно, в этой связи нужно исследовать возможность применения других источников полисахаридов непищевого назначения [4].

Процесс биоразложения биопластиков протекает в 2 стадии. На первой стадии происходит расщепление полимерной цепочки под действием 
биохимических или физических факторов, на второй - усвоение этих остатков микроорганизмами и выделение их в виде метана, углекислого газа и воды [5]. И тут возникает проблема: некоторые БРП фрагментируются с образованием соединений, токсичных для микроорганизмов гораздо сильнее, чем сами полимеры. Это объясняется тем, что в состав многих биопластиков для придания технологических свойств вносят различные добавки (пластификаторы, стабилизаторы и т.д.).

Многие биоразрушаемые пластики являются компостируемыми, т.е. для их деструкции требуются определенные условия, но в России слабо развита инфраструктура сбора, переработки и компостирования отходов. Если компостируемые БРП попадут на обычные свалки как обычный мусор, то они потеряют свое свойство к биоразложению [6].

Во многих странах развитию БРП способствуют правительственные постановления и законодательные акты, а в России их внедрение затрудняется отсутствием поддержки на законодательном уровне.

Однако, глобальная важность решения проблемы замены огромной массы создающего необратимые негативные экологические нагрузки на окружающую среду полимера на биоразлагаемые материалы оптимистично настраивают на активный поиск выхода из этого состояния. 


\section{Литература:}

1. Васильева Н.Г. Биоразлагаемые полимеры // Вестник казанского технологического университета. - 2013. - № 22. - С. 156-157.

2. Валеева Н.Ш., Хасанова Г.Б. Биополимеры - перспективный вектор развития полимерной промышленности // Вестник казанского технологического университета. - 2013. - № 22. - С. 184-187.

3. Киселев Е.Г., Шишацкий О.Н. Разрушаемые биопластики в качестве альтернативы неразрушаемым полиолефинам // Химия в интересах устойчивого развития. - 2012. - № 6. - С. 727-730.

4. Потапов А.Г., Пармон В.Н. Биоразлагаемые полимеры - вперед в будущее // Экология и промышленность России. - 2010. - № 5, спецвыпуск. - С. 48.

5. Алексеев Е.И., Хайруллин Р.З., Янов В.В. Перспективы использования биодеградируемых полимерных материалов для производства гибкой упаковки // Вестник технологического университета. - 2015. - № 15. - С. 187-188.

6. Жоран Реске. Биопластики - перспективы использования // Твердые бытовые отходы. - 2007. - № 11. - С. 60-67. 